\title{
Effects of Hypertriglyceridemia on Streptozotocin-Induced Diabetic Nephropathy in Rats
}

\author{
Hisako Murakami ${ }^{1,2}$, Akitoshi Ichimura' ${ }^{1}$ Kaori Daimaru ${ }^{1}$, Akiko Murata $^{1}$, Itaru Yamaguchi ${ }^{2}$, and \\ Kosaku Fujiwara ${ }^{2}$
}

'Safety Assessment Laboratory, Medical Research Laboratories, Lederle Japan

${ }^{2}$ Department of Pathobiology, Nihon University School of Veterinary Medicine

\begin{abstract}
The effect of hypertriglyceridemia was examined on streptozotocin (STZ)-induced diabetic nephropathy in rats. After repeated intraperitoneal injection with Triton WR-1339 (Triton) in STZ-diabetic rats, food and water consumption and urine volume were significantly decreased and albumin/globulin ratio lowered compared with non-injected Triton and STZdiabetic rats. Between STZ-diabetic rats with Triton injection and those without, no significant difference was observed in the extent of mesangial matrix and PAS, type IV collagen, fibronectin, and laminin positive areas. The results suggested that the proliferation of mesangial cells might be inhibited by the high levels of low and very low density lipoproteins, and diabetic nephropathy was not affected by the inducing of hypertriglyceridemia. (J Toxicol Pathol 1997; 10: 157 164)
\end{abstract}

Key words : Diabetes, Hypertriglyceridemia, Nephropathy, Rat, Streptozotocin

\section{Introduction}

The coronary arterial disorders, arteriosclerosis, nephropathy, neuropathy, and retinopathy are known to be diabetic complications in $\operatorname{man}^{1-5}$. The diabetic nephropathy can be aggravated with hyper-glycemia, hypertension, and excessive protein intake. On the other hand, hyperlipidemia constitutes a major risk for atherosclerotic lesions and recently, it was reported to injure the renal function using animal models ${ }^{6-9}$. However, there has been no evidence of causal relation of hyperlipidemia to diabetes.

A compound [2-deoxy-2-(3-methyl-3-nitrosouredio) D-glucopyranose, $\mathrm{C}_{8} \mathrm{H}_{15} \mathrm{~N}_{3} \mathrm{O}_{7}$ ], streptozotocin (STZ) is a culture extract of Streptomyces acromogenes injuring pancreatic beta cells and inducing diabetes in many species of animals $^{10,11}$. In our previous report ${ }^{12}$, hypercholesterolemia was shown to promote the progression of STZ-induced diabetic nephropathy in rats, but the renal injury caused by hypertriglyceridemia remains unstudied. A lipoprotein lipase (LPL) receptor blocker, Triton WR-1339 (Triton), was described to elicit hypertriglyceridemia rapidly and dosedependently after intravenous or intraperitoneal administration $^{13}$. The present study is to see the effect of Triton-induced hypertriglyceridemia on the STZ-induced diabetic nephropathy in rats.

\section{Materials and Methods}

\section{Animals}

Sprague-Dawley (SD) rats were bred at this laboratory, and 7-week-old male rats weighing 187.8 to $298.8 \mathrm{~g}$, were

村上久子 市村彰敏 大丸 香 村田晃子 山口 格 藤原公策 Accepted for publication : June 29, 1997

Mailing address : Hisako Murakami, Department of Pathology, Safety Assessment Laboratory, Medical Research Laboratories, Lederle (Japan), 1-6-34 Kashiwa-cho, Shiki 353, Japan. individually housed in a stainless steel cage. They were freely given CE-2 pellets (CLEA, Tokyo) and tap water filtered through a Millex-HA ${ }^{\circledR}$ (pore size $0.22 \mu \mathrm{m}$; Millipore Corp., Tokyo). The environment was controlled at $13 \pm 2^{\circ}$ C, $50 \pm 10 \%$ relative humidity, and daily lighting for $12 \mathrm{hr}$.

\section{Chemicals}

STZ and Triton were from Wako Pure Chemical Industries, Osaka and Ruger Chemical Inc., respectively. Rats were injceted intraperitoneally (i.p.) with $50 \mathrm{mg} / \mathrm{kg} /$ day STZ for two consecutive days and $24 \mathrm{hr}$ after the second STZ injection when animals showed glucosuria, a half of STZtreated diabetic rats as well as non-treated controls received i.p. injection of $400 \mathrm{mg} / \mathrm{kg}$ Triton twice a week for 16 weeks.

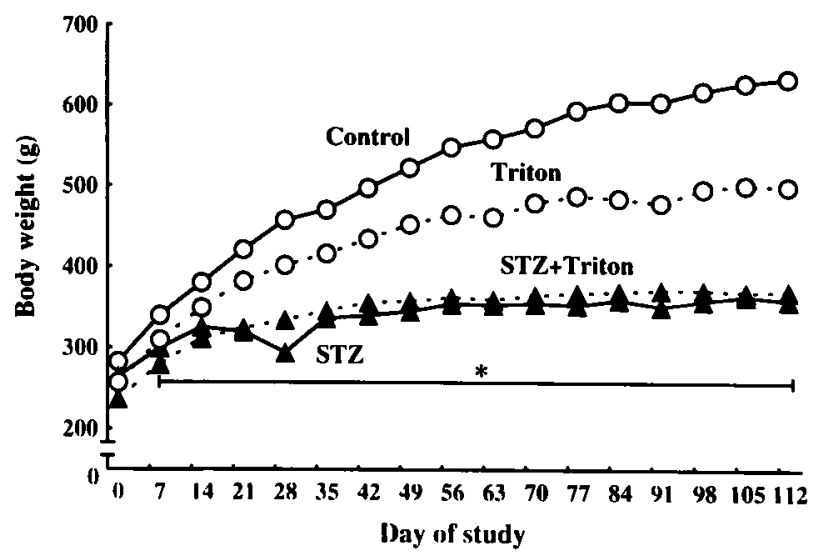

Fig. 1. Body weight. STZ: Streptozotocin $50 \mathrm{mg} / \mathrm{kg}$ i.p. on Days-2 and -1. Triton: Triton WR $1339400 \mathrm{mg} / \mathrm{kg}$ i.p. twice a week throughout the experimental period. Significantly different from the non-treated control group at $\mathrm{p}<0.01\left(^{*}\right)$; from the STZ group at $\mathrm{p}<0.05$ (\#). 


\section{Observation}

Animals were weekly examined for body weight and food consumption, and water consumption and urine volume for a 16-hr-period were measured monthly. The blood and urine were chemically analyzed monthly. Serum samples were kept at $-40^{\circ} \mathrm{C}$ and examined for glucose, total-cholesterol, triglycerides, total protein, albumin, and albumin/ globulin (A/G) ratio using Clinitek 200 (Miles-Sankyo, Tokyo). Urine samples were examined for glucose, creatinine, total protein, and $\mathrm{N}$-acethyl- $\beta-\mathrm{D}$ glucosaminidase (NAG) using $\mathbf{N}$-Multistix ${ }^{\circledR}$ SG and Clinitek ${ }^{\circledR} 200$ (Miles-Sankyo, Tokyo). Urine sediments were subjected to microscopy after staining of Sternheimer. The data were statistically analyzed for using Dunnett's multiple comparison test and $t$-test. Statistical significance was set at $\mathrm{p}<0.05$.

\section{Histopathology}

At the end of the experiments, all rats were exanguinated from the carotid vien under ether anesthesia, and the kidneys were sampled and fixed in $10 \%$ phosphate buffered formalin. Paraffin sections $3 \mu \mathrm{m}$ thick were stained with hematoxylineosin (HE) and periodic acid-Schiff (PAS). A total of $\mathbf{4 0}$ glomeruli from each animal were measured for the mesangial PAS positive matrix areas using MacScope ${ }^{\circledR}$ (Mitani, Tokyo) and Desktop Computer Macintosh Quadra 840AV (Apple Computer, USA) ${ }^{14}$.

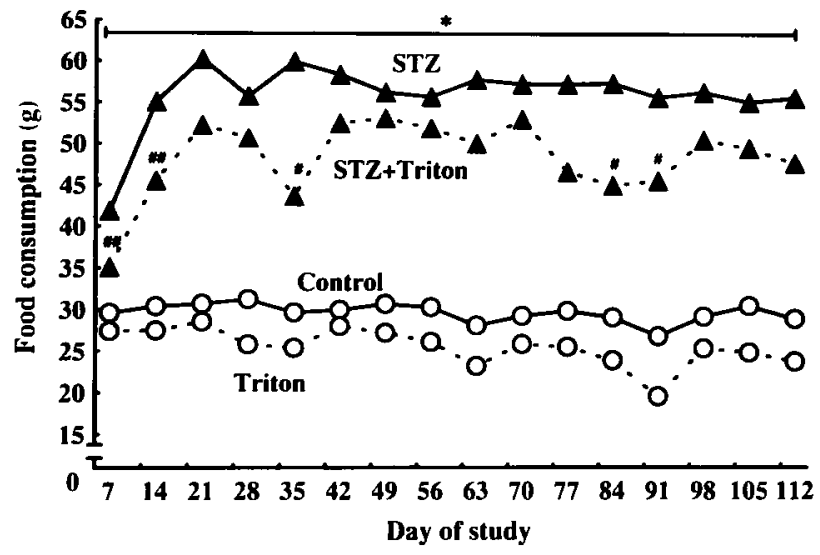

Fig. 2. Food consumption. STZ, Triton: See Fig. 1. Significantly different from the non-treated control group at $p<0.01\left(^{*}\right)$; from the STZ group at $p<0.05$ and $p<$ $0.01(\#, \#)$, respectively
For immunostain paraffin sections were treated with $0.05 \%$ protease type XXVII (Sigma, Tokyo) in Tris- $\mathrm{HCl}$ buffer (pH 7.6) at $37^{\circ} \mathrm{C}$ and then with $0.3 \% \mathrm{H}_{2} \mathrm{O}_{2}$ in methanol and rinsed in PBS. After blocking with $10 \%$ fetal bovine sera (Sigma, Tokyo) in PBS, the sections were incubated at $4^{\circ} \mathrm{C}$ overnight with antibody to fibronectin $(1: 2,000$; Dako, Kyoto), laminin ( $1: 400$; Dako, Kyoto) or type IV collagen (1:2,000; Cosmo Bio., Tokyo). Thereafter sections were incubated with biotinylated rabbit immunoglobulin (Dako, Kyoto, $1: 600$ ) at room temparature for $30 \mathrm{~min}$ and then

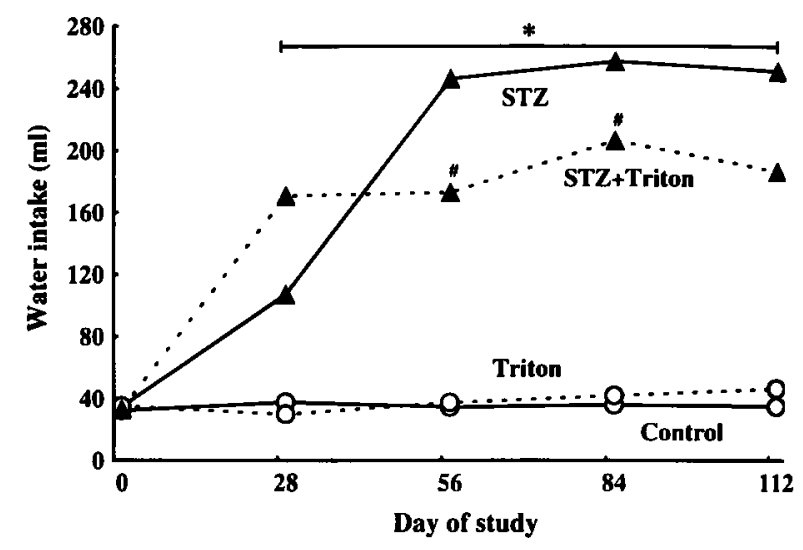

Fig. 3. Water intake. STZ, Triton: See Fig. 1. Significantly different from the non-treated control group at $\mathrm{p}<0.01\left(^{*}\right)$; from the STZ group at $\mathrm{p}<0.05$ (\#).

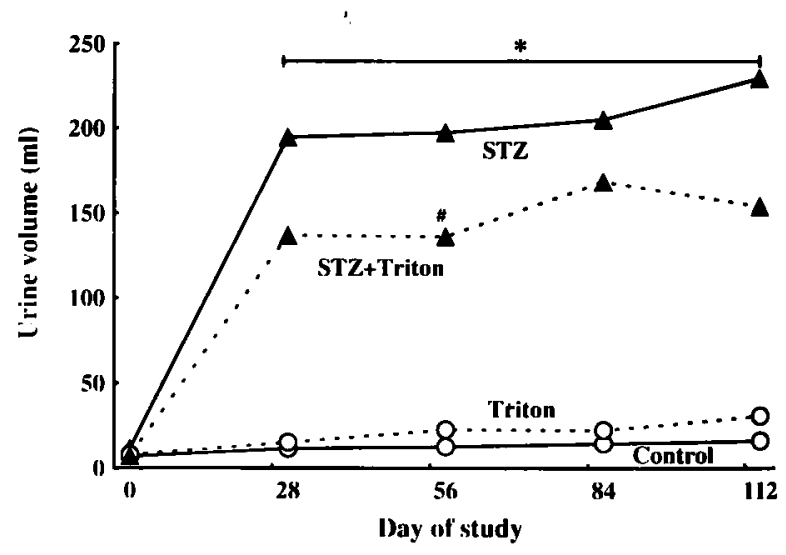

Fig. 4. Urine volume. STZ, Triton: See Fig. 1. Significantly different from the non-treated control group at $\mathrm{p}<0.01\left(^{*}\right)$ and from the STZ group at $\mathrm{p}<0.01$ (\#).

Table 1. Blood Chemistry on Day 112

\begin{tabular}{|c|c|c|c|c|c|c|c|c|}
\hline Group & Treating & $\begin{array}{l}\text { Number } \\
\text { of animals }\end{array}$ & $\begin{array}{c}\text { Glc } \\
\text { (mg/dl) }\end{array}$ & $\begin{array}{c}\text { Chol } \\
(\mathrm{mg} / \mathrm{dl})\end{array}$ & $\begin{array}{c}\mathrm{TG} \\
(\mathrm{mg} / \mathrm{dl})\end{array}$ & $\begin{array}{c}\mathrm{TP} \\
(\mathrm{g} / \mathrm{dl})\end{array}$ & $\begin{array}{c}\text { Alb } \\
(\mathrm{g} / \mathrm{dl})\end{array}$ & $A / G$ \\
\hline A & - & 5 & $122 \pm 19$ & $99 \pm 23$ & $176 \pm 66$ & $7.87 \pm 0.69$ & $2.91 \pm 0.16$ & $0.61 \pm 0.07$ \\
\hline B & STZ & 4 & $556 \pm 110^{* *}$ & $163 \pm 28$ & $303 \pm 238$ & $5.32 \pm 1.24$ & $2.19 \pm 0.19$ & $0.86 \pm 0.55$ \\
\hline $\mathrm{C}$ & Triton ${ }^{55}$ & 7 & $131 \pm 37$ & $878 \pm 479^{* *}$ & $2,540 \pm 896^{* *}$ & $16.80 \pm 5.68^{* *}$ & $3.82 \pm 1.19$ & $0.31 \pm 0.06^{* *}$ \\
\hline D & STZ+Triton & 5 & $553 \pm 40^{* *}$ & $264 \pm 166$ & $537 \pm 326$ & $6.13 \pm 0.96$ & $1.82 \pm 0.36^{*}$ & $0.44 \pm 0.15^{\#}$ \\
\hline
\end{tabular}

§: Streptozotocin $(50 \mathrm{mg} / \mathrm{kg}$ i.p.) on Days -2 and -1 .

\$5 : Triton WR $1339(400 \mathrm{mg} / \mathrm{kg}$ i.p.) twice a week throughout the experimental period.

$*^{*, * *}$ : Significantly different from $A$ at $p<0.05$ and $p<0.01$, respectively.

\#: Significantly different from $B$ at $p<0.05$. 
treated with avidin-biotin complex (ABComplex, Dako, Kyoto) and diaminobentidin (DAB, Wako Pure Chemicals, Tokyo) $-\mathrm{H}_{2} \mathrm{O}_{2}$. They were then counterstained with hematoxylin.

\section{Results}

As shown in Figs. 1 to 4, significant difference was seen throughout the study in body weight, food, and water consumption, and urine volume throughout the study between STZ-diabetic rats and non-diabetic ones. In STZ-diabetic and Triton-treated group, food and water consumption and urine volume were significantly decreased as compared with those without Triton, while Triton had no significant effects on non-diabetic rats.

As shown in Table 1, the albumin level and $A / G$ ratio in STZ-diabetic and Triton-injected rats were significantly lower as compaired with those without Triton. Serum cholesterol, triglyceride, and total protoin levels on Day 112 were remarkably higher and the $A / G$ ratio was lower in non-diabetic and Triton injected rats as compaired with those without Triton. As shown in Table 2, urine glucose values were much greater in STZ-diabetic and Triton-injected rats than those without Triton. In STZ-diabetic rats either or without Triton injection, urine total protein and creatinine were lower than in non-diabetic ones.

No significant difference was observed between those with and without Triton injection in the extent of mesangial matrix, PAS positive areas, and type IV collagen, fibronectin, and laminin positive areas. In STZ-diabetic rats the areas were greater in extent than in non-diabetic ones (Table 3).

In Triton injected either diabetic or non-diabetic animals, foamy cells appeared in the mesangium, and clear cells were seen in the proximal and distal convoluted tubules of diabetic animals (Figs. 5 to 8 ). No ginificant effects of
Triton injection were recognized on staining for collagen IV, fibronectin, and laminin in the glomeruli of STZ-diabetic rats.

\section{Discussion}

Hyperlipidemia is known to cause lipid deposition and production of foamy cells in the renal glomeruli in human cases of nephrotic syndrome and diabetic nephropathy ${ }^{15}$ as well as in abnormal lipid metabolism ${ }^{16}$. Also in animal models for dietary and endogenous hyperlipidemia, hypercholesterolemia has been reported to induce renal failure ${ }^{6,8,9,17}$. Blood coagulation factors $X$ and VII have been described to correlate with serum triglyceride value, suggesting the involvement of hypertriglyceridemia in thrombogenesis ${ }^{18}$. In our previous study ${ }^{12}$, hypercholesterolemia was shown to promote the progression of STZ-induced diabetic nephropathy in rats, and this study is to see the effect of hypertriglyceridemia on nephropathy in STZinuced diabetes rats.

Triton is known to induce elevation of serum triglyceride and cholesterol levels, but in STZ-diabetic and Triton injected rats the levels were not so high probably because of the insulin shortage resulting in decreased synthesis and secretion of low density lipoprotein (LDL) as well as very low density lipoprotein (VLDL), while the elimination of VLDL and LDL might be inhibited in diabetic rats ${ }^{19}$. The total protein and albumin levels and $A / G$ ratio remained unchanged after Triton treating in STZ-diabetic animals as in non-diabetes ones. The lower serum levels of LDL and VLDL have been reported to induce increased number of mesangial cells in vitro ${ }^{20}$, whereas the higher levels inhibit their proliferation. In this study, Triton-induced hypertriglyceridemia might have resulted in a high level of VLDL, inhibiting not only the proliferation of mesangial cells but

Table 2. Urine Chemistry on Day 112

\begin{tabular}{ccccccc}
\hline Group & Treating & $\begin{array}{c}\text { Number } \\
\text { of animals }\end{array}$ & $\begin{array}{c}\text { Glc } \\
(\mathrm{mg} / \mathrm{dl})\end{array}$ & $\begin{array}{c}\text { TP } \\
(\mathrm{mg} / \mathrm{dl})\end{array}$ & $\begin{array}{c}\text { Cr } \\
(\mathrm{mg} / \mathrm{dl})\end{array}$ & $\begin{array}{c}\text { NAG } \\
(\mathrm{U} / \mathrm{l})\end{array}$ \\
\hline A & - & 5 & $23 \pm 9$ & $1,080 \pm 400$ & $109 \pm 51$ & $25 \pm 15$ \\
B & STZ & 4 & $2,321 \pm 1,703^{* *}$ & $376 \pm 253^{*}$ & $18 \pm 5^{* *}$ & $10 \pm 6^{*}$ \\
C & Triton & 7 & $18 \pm 4$ & $891 \pm 885$ & $89 \pm 21$ & $29 \pm 11$ \\
D & STZ+Triton & 5 & $6,099 \pm 4,307 * * *$ & $296 \pm 409 * * *$ & $27 \pm 28^{* *}$ & $13 \pm 9$ \\
\hline
\end{tabular}

See the foot-notes on Table 1.

${ }^{*, * *}$ : Significantly different from $A$ at $p<0.05$ and $p<0.01$, respectively.

\#," : Significantly different from $B$ at $p<0.05$ and $p<0.01$, respectively.

Table 3. Extent of Glomerular PAS Positive Areas

\begin{tabular}{cccccc}
\hline Group & Treating & $\begin{array}{c}\text { Number } \\
\text { of animals }\end{array}$ & $\begin{array}{c}\text { Glomerulus } \\
\left(\mu \mathrm{m}^{2}\right)\end{array}$ & $\begin{array}{c}\text { PAS positive area } \\
\left(\mu \mathrm{m}^{2}\right)\end{array}$ & $\begin{array}{c}\text { PAS positive area/ } \\
\text { Glomerulus }\end{array}$ \\
\hline A & - & 5 & $20,157 \pm 1,131^{* *}$ & $3,541 \pm 126$ & $17.7 \pm 0.9$ \\
B & STZ $^{\text {S }}$ & 4 & $21,895 \pm 2,096$ & $5,149 \pm 753^{* *}$ & $24.7 \pm 1.7^{* *}$ \\
C & Triton $^{55}$ & 7 & $20,338 \pm 2,451$ & $3,324 \pm 716^{*}$ & $16.3 \pm 2.8$ \\
D & STZ+Triton & 5 & $20,620 \pm 2,143^{* *}$ & $4,914 \pm 341^{* *}$ & $24.1 \pm 2.3^{* *}$ \\
\hline
\end{tabular}

See the foot-notes on Table 1 .

*** : Significantly different from $A$ at $p<0.05$ and $p<0.01$, respectively. 

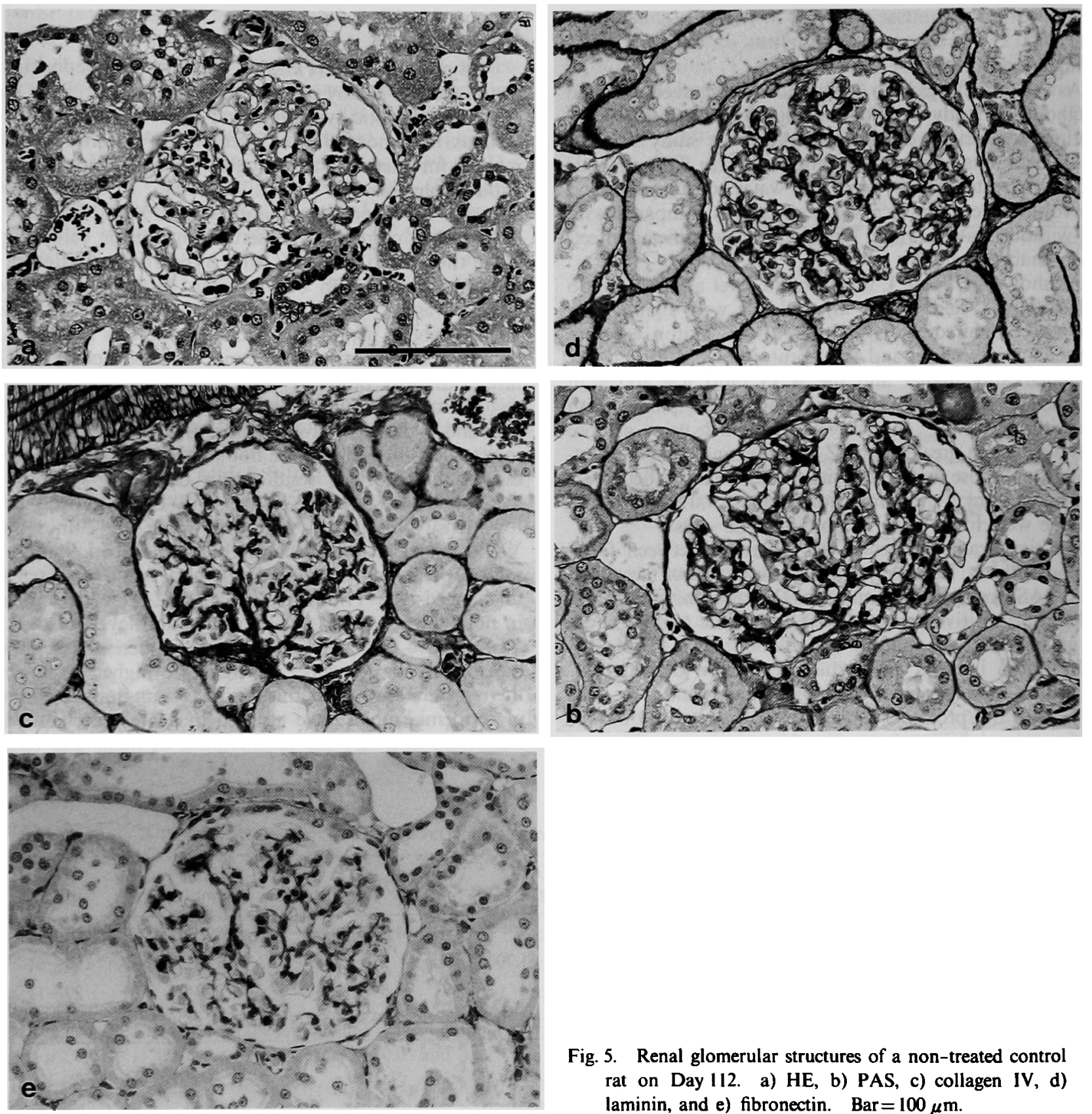

Fig. 5. Renal glomerular structures of a non-treated control rat on Day 112. a) HE, b) PAS, c) collagen IV, d) laminin, and e) fibronectin. $B a r=100 \mu \mathrm{m}$. 

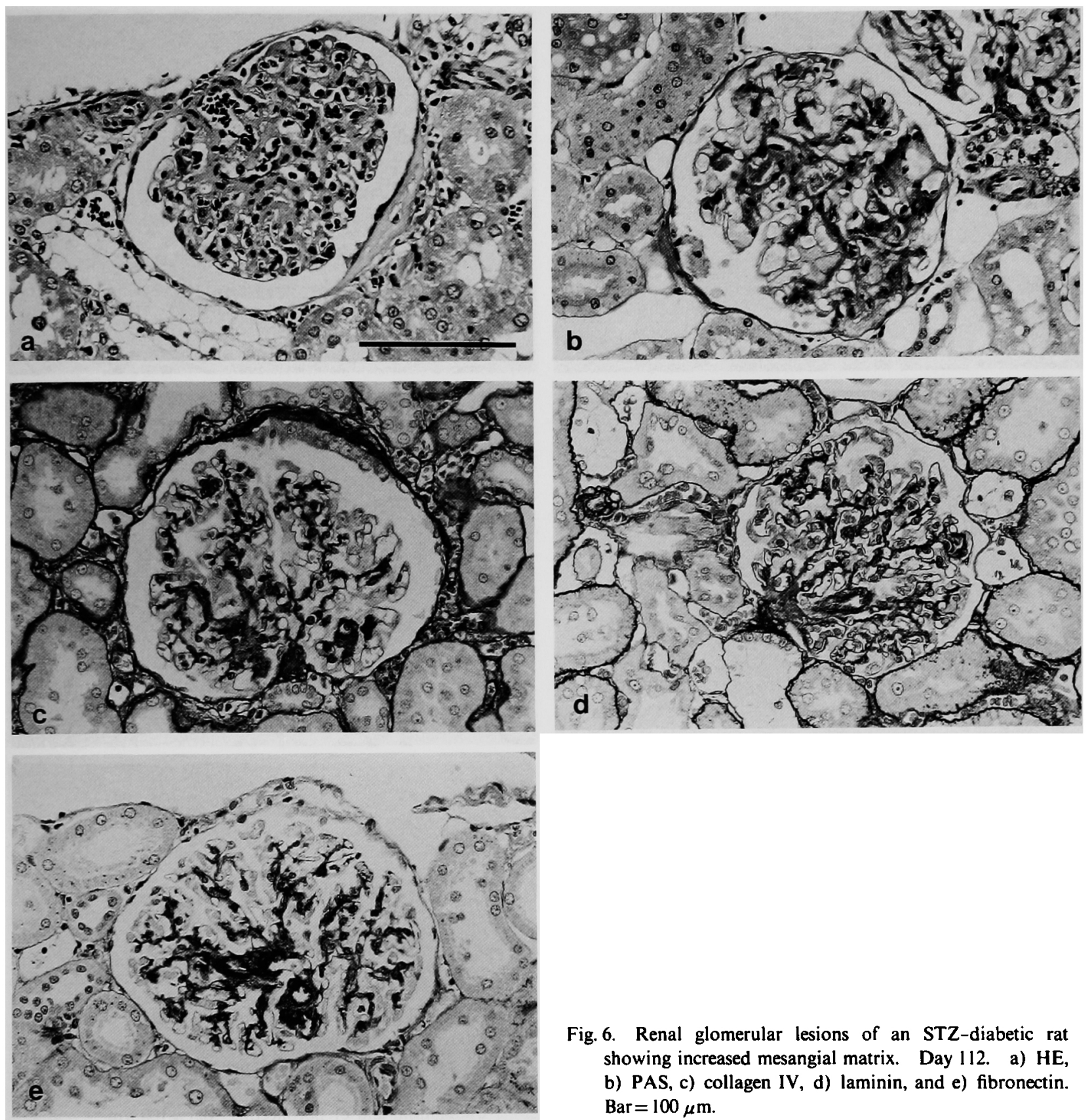

Fig. 6. Renal glomerular lesions of an STZ-diabetic rat showing increased mesangial matrix. Day 112 . a) HE, b) PAS, c) collagen IV, d) laminin, and e) fibronectin. $\mathrm{Bar}=100 \mu \mathrm{m}$. 

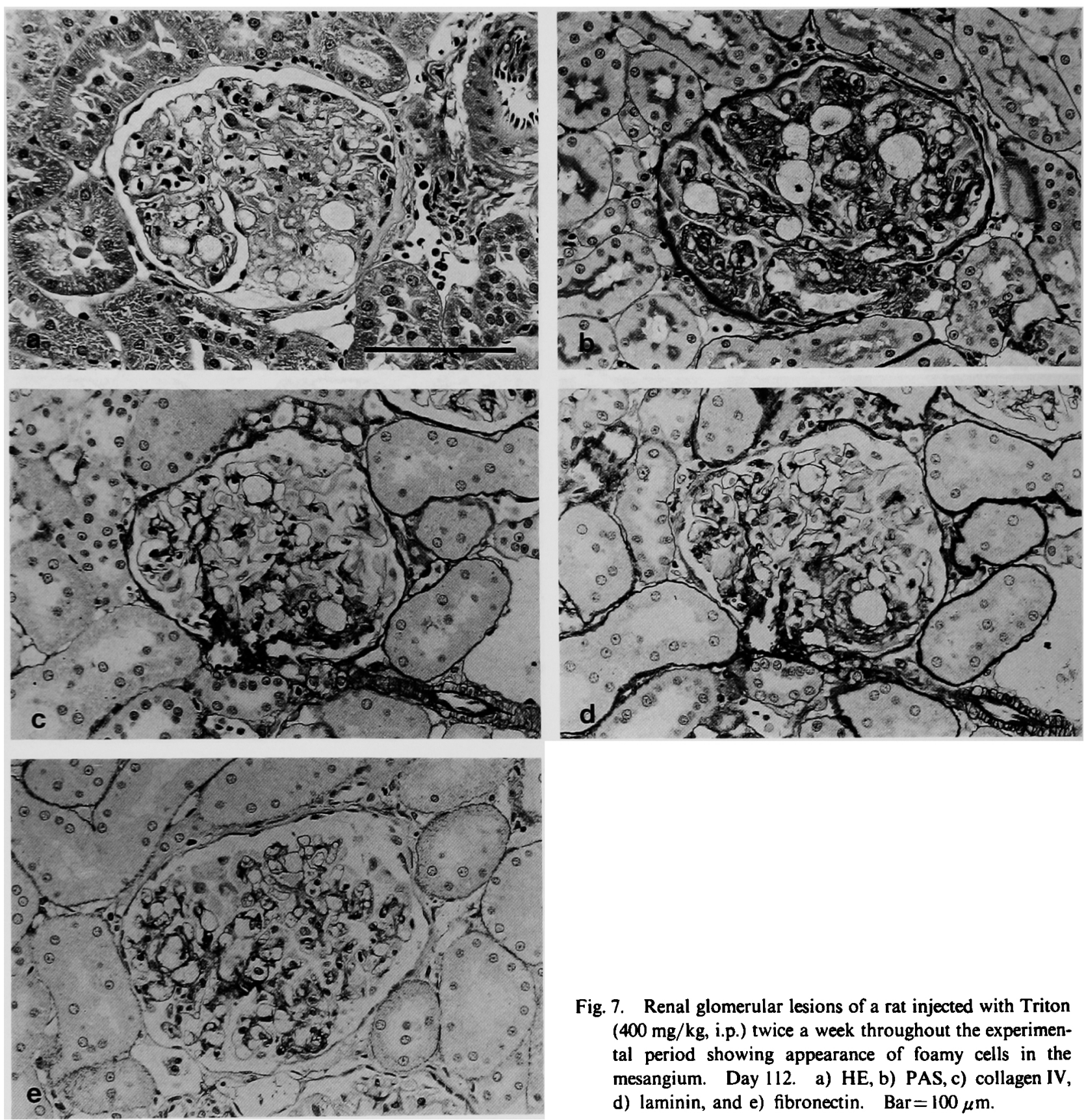

Fig. 7. Renal glomerular lesions of a rat injected with Triton $(400 \mathrm{mg} / \mathrm{kg}$, i.p.) twice a week throughout the experimental period showing appearance of foamy cells in the mesangium. Day 112 a) HE, b) PAS, c) collagen IV, d) laminin, and e) fibronectin. $\mathrm{Bar}=100 \mu \mathrm{m}$. 

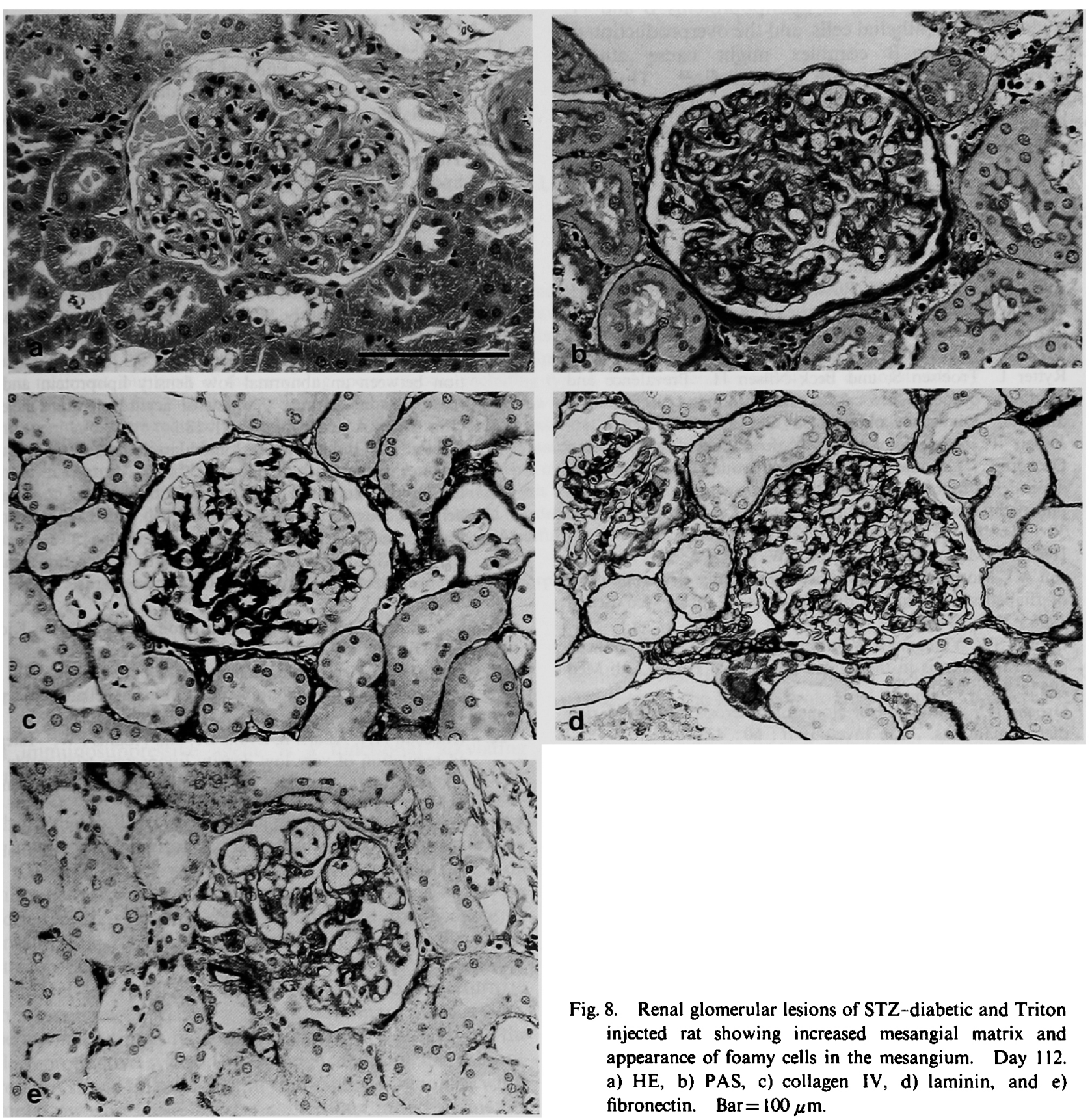

Fig. 8. Renal glomerular lesions of STZ-diabetic and Triton injected rat showing increased mesangial matrix and appearance of foamy cells in the mesangium. Day 112 . a) HE, b) PAS, c) collagen IV, d) laminin, and e) fibronectin. $B a r=100 \mu \mathrm{m}$. 
also the production of type IV collagen, laminin, and fibronectin without causing any renal injuries. On the other hand, the higher concentration of VLDL has been described to enhance the incorporation of apolipoproteins-B and $-E$ into the glomerular epithelial cells, and the overproduction of VLDL-apolipoprotein-B complex might cause atheroscrelosis in diabetic patients with lipidemia ${ }^{21-23}$. Thus, the control of blood lipid levels might be important, although diabetic nephropathy did not take turn for the worse in hypertriglyceridemia in this study.

\section{References}

1. Wilens SL and Elster SK. The role of lipid deposition in renal arteriosclerosis. Am J Med Sci 1951 ; 219 : 183-96.

2. Fuller, JH, Shipley, MJ, Rose, G, Jarrett, RJ, and Keen, H. Mortality from coronary heart disease and stroke in relation to degree of glycemia : the Whitehall Study. BMJ 1983; 287: 867-70.

3. Rytter L, Troelsen S, and Beck-Nilsen H. Prevalence and mortality of acute myocardial infarction in patients with diabetes. Diabetes Care $1985 ; 8: 230-34$.

4. Jensen $T$, Borch-Johnsen $K$, Kofoed-Enevoldsen $A$, and Deckert T. Coronary heart disease in young Type 1 (insulindependent) diabetic patients with and without diabetic nephropathy: incidence and risk factors. Diabetologia 1987; 30 : 144-48.

5. Herlitz J, Malmberg K, Karlson BW, Ryden L, and Hjalmarson A. Mortality and morbidity during a five-year follow-up of diabetics with myocardial infarction. Acta Med Scand $1988 ; 224: 31-38$.

6. French SW, Yamanaka W, and Ostwald R. Dietary induced glomerulosclerosis in the guinea pig. Arch Pathol Lab Med $1967 ; 83$ : 204-10.

7. Groene HJ. Induction of glomerularsclerosis by a lipid-rich diet in male rats. Lab Invest $1967 ; 60: 433-46$.

8. Kasiske BL, O'Donnell MP, Cleary MP, and Keane WF. Effects of reduced renal mass on tissue lipids and renal injury in hyperlipidemic rats. Kidney Int 1989; 37: 40-7.

9. Kasiske BL, O'Donnell MP, Schmitz PG, Kim Y, and Keane WF. Renal injury of diet-induced hypertriglyceridemia in rats. Kidney Int $1990 ; 37: 880-91$.

10. Rakieten N, Rakieten ML, and Nadkarni MV. Studies on the diabetogenic action of streptozotocin. Cancer Chem Rep 1963 ; 29 : 91-98.

11. Like AA and Rossini AA. Streptozotocin induced pancreatic insulitis: new model of diabetes mellitus. Science 1976; 193 : 415-17.

12. Murakami H, Ichimura A, Daimaru K, Murata A, Yamaguchi $\mathbf{I}$, and Fujiwara $\mathbf{K}$. Effect of hypertriglyceridemia in streptozotocin-induced nephropathy in diabetic rats. $\mathrm{J}$ Toxicol Pathol 1996; 9 : 341-50.

13. Kiriakov A, Apostolova Iu, Kavrukova Iu, Volkova S, and Tinterova, Z. In vivo effects of triton WR 1339 on plasma lipoproteins and the postheparin activity of lipoprotein lipase and liver triglyceride lipase. Eksp Med Morfologiia 1985; 24: $56-62$.

14. Suzuki D. Measurement of the extracellular matrix in glomeruli from patients with diabetic nephropathy using an automatic image analyzer. Jpn J Nephrol $1994 ; 36$ : 1209-15.

15. Wilens SL and Elster SK. The role of lipid deposition in renal arteriosclerosis. Am J Med Sci 1951 ; 219 : 183-86.

16. Gjone E, Blomhoff JP, and Skarbovik AJ. Possible association between an abnormal low density lipoprotein and nephropathy in lecithin; Cholesterol acyltransferase deficiency. Clin Chem Acta 1974; 54 : 11-18.

17. Groen HJ. Induction of glomerularsclerosis by a lipid-rich diet in male rats. Lab Invest 1937 ; 433-46.

18. DeSausa J, Soria C, and Ayarault-Jarrier M. Association between coagulation factor VII and X with triglyceride rich lipoproteins. J Clin Pathol 1988; 41 : 940-44.

19. Yoshino G. Effect of dietary fructose on triglyceride turnover in streptozotocin-diabetic rats. Atherosclerosis 1989; 79: 41-46.

20. Suzuki M. Hyperlipidemia and glomerulus injury. Kidney and Dialysis 1991 ; 30 : 33-37.

21. Grone HJ. Receptor mediated uptake of apoB and apoE rich lipoproteins by human glomerular epithelial cells. Kidney Int $1990 ; 37: 1149$.

22. Kissebah AH, Alfarsi S, Evans DJ, and Adams PW. Integrated regulation of very low density lipoprotein triglyceride and apolipoprotein-B kinetics in non-insulin-dependentent diabetes mellitus. Diabetes $1982 ; 31: 217-25$.

23. Mamo JC, Szeto K, and Steiner G. Glycation of very low density lipoprotein from rat plasma impairs its catabolism. Diabetologia $1990 ; 33$ : 39 . 